they will need careful consideration and discussion; nevertheless, more adequate accommodation for the collections of the Science Museum seems at last to be in sight. The formation of a collection of ship models at the National Maritime Museum has raised the question of what should be the appropriate spheres of this Museum and the Science Museum in representing naval architecture; the Commission has gone carefully into the matter and has proposed certain broad principles of development which it recommends for future guidance. The abolition of fees for admission to museums and galleries, where these are still imposed, is strongly recommended.

\section{Man or Gannets}

A CIRCular letter, signed by Sir Montagu Sharp, chairman of the Royal Society for the Protection of Birds, and Mr. John M. Crosthwaite, honorary secretary of the Scottish Society for the Protection of Wild Birds, has been received by NATuRE and has been widely circulated in the daily newspapers. It states that the inhabitants of Lewis capture and preserve for winter food some two thousand nestling gannets, after a journey over some 40 miles of open sea to the uninhabited islet of Sula Sgeir ; sarcastic comment is made on "the apparent plight of the inhabitants . . . that of necessity they have to eat Gannets", and suggests that this wilful destruction of these birds for human food should be stopped. The letter further states, inaccurately, that such slaughter is without precedent in Great Britain. This is scarcely correct. Historically, the use for human food of the nestlings of the birds which fre. quent certain bird rocks in Scotland in great numbers is an ancient practice which throughout centuries has made no appreciable difference to the bird populations. In Edinburgh the nestlings of gannets from the Bass Rock used to be sold in the streets, as a luxury and not as something which suggested the plight of starvation or lack of "sufficient food of a more ordinary and palatable kind", as the signatories describe it. At the time when St. Kilda was most prosperous, its people preserved and fed annually upon, not two thousand, but many thousands of fulmar petrels, and if the stoppage of that source of food supply has had any effect upon the fulmar population, it has been to threaten to make that bird a nuisance on certain parts of the coast of the mainland.

THE circular states that in order to bring about the protection of gannets of Sula Sgeir, the County Council was approached by the signatories or the societies they represent and "urged" to take the necessary action to make this island a bird sanctuary, so that the men of Ness could be prosecuted if they took the birds. The County Council refused to take any steps in the matter on the grounds that the gannets constituted in money and food a great aid to the livelihood of the people of Ness. Presumably the County Council, composed of local representatives, knows what it is talking about, and presumably some urge greater than useless destruction causes these crofters of Ness to cross forty miles of the open Atlantic and to spend an uncomfortable fortnight on an isolated island collecting these winter food stores. But a curious situation has been reached when sentimental regard would insist that the welfare of birds should be preferred to the welfare of human beings.

\section{Influence of Science on Current Thought}

The fifth lecture of a series on the influence of science and research upon current thought, established by the Carnegie Institution of Washington in honour of Mr. Elihu Root, who was, until his death last year, a member of the board of trustees of the Institution and its chairman during the last twentyfour years of his life, will be delivered by Sir Richard Gregory in the Institution's new auditorium on December 8. The subject will be "Cultural Contacts of Science" ; and the lecture will, therefore, be concerned mainly with associations of science with religion, literature and other aspects of intellectual development and social evolution, rather than with the services rendered to modern communities by utilitarian applications of scientific knowledge. As Mr. Root was deeply interested in the relation between the advance of science and development of human values, it is appropriate that this should be the general theme of the series of lectures bearing his name. The lectures are published in book form after their delivery. The subject of the fourth lecture in the series was "The Concept of Uniformity : Growth and Reactions", by Dr. F. H. Seares, assistant director of Mount Wilson Observatory.

\section{Roman Dorchester}

ON September 26 the foundation stone of the new Shire Hall in Colliton Park, Dorchester, was laid by Lord Shaftesbury. This building is probably unique in Great Britain in that it is the first to be erected on the site since Roman times, and also because there will stand near by, permanently preserved, one of the residential buildings of the Roman town of Durnovaria, brought to light by the excavations of the Dorset Natural History and Archæological Society, which were initiated under the direction of Lieut.Colonel C. D. Drew when attention was directed to the existence of Roman remains at this point by the preparations for building. Further discoveries are still being made. Colonel Drew records the discovery of a fine tessellated pavement of geometrical design. It had been broken in ancient times, and in the fracture was found a delicate Roman balance in bronze, which probably had been used for goldsmith's work. The beam was three inches long only. One of the pans was intact, the other in fragments. The pavement is to be removed to the adjacent Roman dwelling, and the balance has been set up in the Dorchester Museum. Further work in the examination of the neighbouring town wall in the North Walk reveals that on this side there was no stone wall, such as was found recently below Colliton Walk. Here an earthen rampart had the natural reinforcements of the river and marshy ground. 